\title{
Yttrium Y 90 Anti-CEA Monoclonal Antibody cT84.66
}

National Cancer Institute

\section{Source}

National Cancer Institute. Yttrium Y 90 Anti-CEA Monoclonal Antibody CT 84.66. NCI

Thesaurus. Code C77885.

A radioimmunoconjug ate comprised of a chimeric monoclonal antibody ag ainst human carcinoembryonic antigen (CEA) conjug ated with the radioisotope yttrium 90 (Y-90) via the chelator tetra-azacyclododecanetetra-acetic acid (DOTA) with potential antineoplastic activity. The antibody moiety of yttrium Y90 DOTA anti-CEA monoclonal antibody CT 84.66 binds to cells expressing the CEA antigen. Upon cellular internalization, this agent selectively delivers a cytotoxic dose of beta radiation. CEA, a tumor associated antigen, is overexpressed in many cancer types, including gastrointestinal, breast, nonsmall cell lung, and thyroid cancers. 